US patent for Montagnier

\section{Washington}

A US PATENT for HIV-2, the second virus found to cause AIDS, has been granted to Luc Montagnier of the Institut Pasteur in Paris. The all-encompassing patent - it has a total of 48 claims - was announced last week by the US drugs company Bristol-Myers, whose subsidiary Genetics Systems Corporation holds the exclusive rights for diagnostic applications.

The granting of the patent may reopen discord between US and French AIDS researchers. Priority for the discovery of HIV-1, the virus causing the majority of AIDS cases outside Africa, was hotly contested for several years in US patent battles involving Montagnier and Robert Gallo of the US National Cancer Institute. Although Montagnier and Gallo have said the dispute did not affect the "spirit of scientific cooperation" between their two laboratories, it eventually escalated to include both the French and US governments.

In early 1987, the Institut Pasteur and the US Department of Health and Human services signed a settlement agreeing that the antibody test kit for HIV-1 was a "joint invention", based on a chronology of AIDS discoveries (see Nature 326, 435; 1987). The terms of the settlement also dictated that 80 per cent of the royalties resulting from the sales of HIV (humanimmunodeficiency virus) antibody screening kits would be donated to the French and American AIDS Foundation, with a portion going to the World AIDS Foundation.

Montagnier's HIV-2 patent's first and broadest claim reads "A human retrovirus, wherein the retrovirus is HIV-2 in a biologically pure form". But the subsequent 47 claims cover every possible facet of HIV-2: in vitro cultures, supernatants, lysates and extracts; various combinations of labelled and unlabelled viral proteins that could be used in blood tests; and specific dosages of various protein "compositions" that could be used in a potential vaccine.

The patent was filed in March 1986, and rests on work done in late 1985 and early 1986 on cultured lymphocytes from a person with AIDS from Guinea-Bissau who did not test positive on an antibody test for HIV-1. But Myron Essex from the Harvard School of Public Health was also involved in research at about the same time on a virus that was also later designated HIV-2.

Harvard University has filed patents based on work dore in his laboratory which could turn out to coincide with the discoveries underlying Montagnier's patent, throwing it open to an 'interference' investigation by the US Patent Office. Essex is a consultant for Cambridge BioScience, a Massachussetts bio-technology company that has been developing screening tests for HIV-2.

The potential market for a separate diagnostic test for HIV-2 is a fraction of the $\$ 100$ million market for HIV-1. The utility of such tests is debatable: because current tests for HIV-1 antibodies identify between 50 and 90 per cent of those infected with HIV-2, a test for HIV-2 would detect only a few additional cases. Most of those infected with HIV-2 are in Africa.

Montagnier's patent issued quietly last month, with many of the central players in AIDS research and policy getting wind of it only late last week. Gallo, who along with Montagnier is also one of the directors of the World AIDS Foundation, says he is "surprised and concerned" that Mon-

\title{
French haemophiliacs awarded damages
}

\section{Paris}

FRENCH haemophiliacs infected with the AIDS virus through transfusions of contaminated blood products will begin receiving compensation from September this year. Systematic screening of blood products was introduced in France on 1 August 1985 but by then almost 1,500 of the 3,500 haemophilia sufferers had been infected. Of this number, about 200 have developed AIDS and 80 have died.

A two-tier trust fund has now been set up by the Ministry of Health and Social Security and private health insurance companies. The state fund is to be financed through the new government association for the campaign against AIDS and will be reserved for confirmed AIDS sufferers. These will receive between FF30,000 $(\$ 4,800)$ and FF170,000 $(\$ 27,200)$ accord-

ing to their personal and family circumstances. Private health insurance companies, which will receive tax benefits partially to offset the burden of the compensations, will make payments to seropositive haemophiliacs (FF100,000) and their seropositive partners, if these were contaminated through sexual relations (FF100,000). The family of a haemophiliac who has died of AIDS will be eligible for compensation of up to $\mathrm{FF} 225,000(\$ 36,000)$.

The fund will be managed by the Fondation de France in collaboration with the French haemophilia association. The awards are unusual in that state responsibility, through the national blood transfusion service, has not been proven in the courts. A condition of the awards, however, is that individuals agree not to take legal action.

Peter Coles tagnier's proprietary interests in HIV-2 were not disclosed when the HIV-1 settlement was reached in 1987 . He says the new patent is "worth a significant discussion, if not more". Montagnier declined to comment without first reviewing his background materials.

Carol EzzellI

\section{ROCKET LAUNCHERS}

\section{Engine problems shake Japan's space plans Tokyo}

JAPAN's plan to build a domestically developed rocket for the launch of large satellites has suffered a serious setback. The National Space Development Agency (NASDA) says that the first launch of the $\mathrm{H}-\mathrm{II}$ rocket will have to be delayed a year because of problems in the development of the cryogenic oxygen-hydrogen engine in the first stage of the rocket.

The H-II will be Japan's first domestically developed liquid-fuel rocket and will be capable of putting a 2,000-kg satellite into geostationary orbit - almost four times the payload capacity of the $\mathrm{H}-\mathrm{I}$ rocket now in use. The rocket is expected to compete with those of other nations for the commercial launch of satellites.

But NASDA's contractors are having serious problems with the first-stage engine. In test runs the nickel-alloy turbine blades of the hydrogen turbopump, used for pumping the liquid hydrogen fuel, resonate and crack. This problem was not encountered with the second-stage cryogenic engine of the $\mathrm{H}-\mathrm{I}$, which also forms the second stage of the $\mathrm{H}$-II, because it operates at much lower pressures and is simpler in design.

Resonance was also a problem in the development of the cryogenic engine of the US space shuttle, according to Tateo Arimoto of NASDA's international affairs division, and NASDA is seeking information from the US National Aeronautics and Space Administration (NASA) to try to solve the problem, which, according to Arimoto, may require thickening and redesign of the turbine blades.

The first test launch of the H-II originally scheduled for early 1992 has been postponed until 1993, and this will cause delays in the subsequent launch of NASDA satellites. For example, the Space Flyer Unit, a multi-use platform being developed by NASDA, the Ministry of International Trade and Industry and the Institute of Space and Astronautical Sciences, will now be launched along with a geostationary meteorological satellite (GMS-5) in early 1994 instead of early 1993. And the launch of the Advanced Earth Observing Satellite (ADEOS), which at one time was tentatively scheduled for 1993 (later changed to 1994), is now postponed until early 1995 .

David Swinbanks 